\title{
Active Learning, Students Who Are Academically At-Risk, and Institutional Classification
}

\author{
MA Higgs, Department of University Studies, Middle Tennessee State University \\ Christina Cobb, Department of University Studies, Middle Tennessee State University \\ Pamela Morris, Department of University Studies, Middle Tennessee State University
}

https://doi.org/10.36896/4.1fa2

\section{ABSTRACT}

In this study, self-reported survey results from the National Survey of Student Engagement (NSSE) 2017 and 2018 are examined to understand the extent to which students who were academically at-risk and academically prepared engaged in active learning versus traditional learning methods across bachelor's, master's, and doctoral degreegranting institutions. The NSSE Report Builder Public (2018) was utilized to create a data set from first year student responses selecting for teaching methodologies, Carnegie Institutional Categories, and student academic level as determined by course grades. Researchers used chi-square analyses to establish associations between the variables; all chi-square results were statistically significant except for one; there was no association found between students who were academically at-risk and coursework that emphasized evaluative learning activities. Next, researchers analyzed the frequencies of types of learning activities reported by students. Students who were were academically at-risk reported lower frequencies of using active learning techniques and tended to engage in study for fewer hours across all institution types. From this analysis, suggestions for improving the instruction for students who are academically at-risk include increased use of active learning teaching strategies for the various types of degree-granting institutions.

Keywords: students who are academically at-risk, active learning, Carnegie Institutional Categories

$\mathrm{n}$ higher education, institutions at all levels are challenged to meet students' academic, social, and personal needs. Whether the institution grants bachelor's, master's, or doctoral degrees, more and more students enroll with academic needs, Brothen and Wambach (2012) stated, "Policy makers can argue over which institutions should provide access to nontraditional students, but the reality is that most institutions will serve at least some students who are underprepared relative to their peers" (p. 38). Brothen and Wambach further suggested it is not important to worry about whether an institution will serve students who are underprepared but rather how are they going to reach the students and bring them up to college readiness. With students who are underprepared needing assistance to reach college-level readiness, teaching students active learning strategies may be a way to reduce academic barriers and to increase overall student success. Indeed, when compared to traditional teaching methods, active learning techniques were found to enhance student performance (McCarthy \& Anderson, 2020).

With the nation's focus on preparing a better workforce, redesigning first year and developmental coursework by embedding active learning strategies will help students get a better start on their college educations (Lumnia Foundation, n.d.). The purpose of this study is to consider what types of instruction and learning activities are reported by students who are academically successful and academically at-risk in the first year of studies at degree-granting higher education institutions in the United States, specifically at bachelor's-, master's-, or doctoral- degree granting institutions. By considering types of instruction, namely active learning and traditional modes of learning, the

\section{Corresponding Author}

Dr. MA Higgs, Department of University Studies Middle Tennessee State University

1301 E Main St | Murfreesboro, Tennessee 37132

Email: ma.higgs@mtsu.edu 
researchers provide implications for instruction for students who are academically at-risk during the first year of higher education. Namely, if the appropriate instructional methods are utilized, then students who are academically at-risk may have a better chance of success in completing their freshman level coursework and be better equipped for their next academic steps.

\section{Operational Definitions}

The following are definitions of terms and phases specific to the current study.

Students who are academically at-risk are those who reported final grades of $\mathrm{C}$ or lower in first year courses. This grade benchmark corresponds to the National Survey of Student Engagement (NSSE) division of grades into "A \& B" or "C or lower" (NSSE Report Builder-Public, 2018, Grades section).

Students who are academically prepared are students who reported A or B in first year courses. This grade benchmark corresponds to the NSSE division of grades into "A \& B" or "C or lower" (NSSE Report Builder-Public, 2018, Grades section).

\section{Carnegie Classifications}

is a modified version of the Basic Classification of the Carnegie Classification of Higher Education Institutions (CCHEI) used by the researchers for this study. Rather than the nine types of institutions of higher education in the Basic Classification, this study uses three institutional types: bachelor's, master's, and doctoral degree-granting institutions.

Active learning is an ambiguous concept (Lombardi \& Shipley, 2021) that may be defined as any instructional tool that involves students during their educational development (Prince, 2004).

As Lombardi and Shipley (2021) indicated active learning may be viewed "as a generalized instructional process (a) for constructing knowledge and (b) for deepening engagement" or "as (a) antithetical to passive learning and (b) antithetical to lecture" (p. 10). For this study, "Applying facts, theories, or methods to practical problems or new situations... Analyzing an idea, experience, or line of reasoning in depth by examining its parts... [and] Evaluating a point of view, decision, or information source" (NSSE, 2015, p. 1) are considered active learning strategies because students are actively engaging with the content.
Also, the number of hours spent in learning activities is taken to be a measure of active engagement with the class. While some fields require more out-of-class activities, weekly self-reported study time that is less than the same number of enrolled credit hours may not be enough course engagement to be successful. Therefore, hours of study is viewed as an indicator of engagement with the coursework.

In traditional learning, the teacher is the primary giver of all information learned in these types of courses. Lessons are usually taught through lectures and memorization. Lecture-based teaching does not promote active learning (Lombardi \& Shipley, 2021). For this study, "memorizing course material" is considered traditional learning (NSSE, 2015, p. 1).

\section{Literature Review}

In this literature review, we will consider active learning teaching strategies; active learning and its relationships to Bloom's Revised Taxonomy; and how institutional type is defined by the Carnegie Classification. This relevant literature frames our study and identifies current research gaps.

\section{Active Learning Teaching Strategies}

Learning strategies are procedures and practices used by faculty to increase student learning (Rachal et al., 2007). Traditional lectures and memorization are still a leading form of undergraduate instruction. The traditional method of teaching, sometimes called lecture-based teaching, is viewed as a classroom where students are listening to the teacher lecture, copying notes, memorizing facts, and working independently (Shi et al., 2018). This traditional approach for teaching involves memorization and limited student classroom engagement. Lecture-based teaching (traditional) is also when the teacher is the primary giver of all information learned (Shi et al., 2018).

Different learning strategies may have differing success with various student populations. For example, one study indicated that high course withdrawals and failure rates may be the result of student boredom with classes in which skill and drill activities have little to do with their college-level courses (Grubb \& Associates, 1999). Students tend to be more involved and have self-efficacy when they are in an engaging learning environment (Churach \& Fisher, 
2001). Student engagement is defined as having students actively involved and contributing to the lesson by using resources and persistence in learning (Rachal et al., 2007). One approach to an engaging learning environment is utilizing active teaching strategies in order to engage students in active learning. Meyers and Jones (1993) stated that active learning originated from the two basic expectations that "learning is by nature an active endeavor and that different people learn in different ways" (Meyers \& Jones, 1993, p. xi). Taken together, it is imperative to have multiple strategies to use in the classroom to keep students engaged and motivated to learn.

There are a variety of active learning teaching strategies. Some examples include learning communities (Boylan et al., 2005), cooperative groups (Opdecam et al., 2014), the flipped classroom model (Zamora-Polo et al., 2019), High-impact Practices (HIPs) (Kuh et al., 2017), and gamification (Fulks \& Lord, 2016). Boylan et al. (2005) proposed using learning communities, also called cohorts, in developmental education, and further suggested that learning communities, which involve students taking coursework together or living as a group, allowed students to feel more comfortable and encouraged to participate in the classroom. Cooperative groups are also another way to involve students actively during the course and are one of the most commonly used methods. In cooperative learning, students are arranged into small clusters to finish an assignment, find solutions, or examine a situation (Opdecam et al., 2014). A flipped classroom (Zamora-Polo et al., 2019) involves students preparing for work outside of class and finishing practicing inside the classroom. This strategy encourages students to be self-reliant. High-impact practices use a variety of tools, such as internship and global learning (study abroad), to engage the learner in the academic process, and many are measurable (Kuh et al., 2017). Gamification is using gaming strategies to teach content or to evaluate mastery (Fulks \& Lord, 2016). Numerous other forms of active learning teaching strategies exist.

Nolting reported in an interview with Boylan (2011) that students in developmental courses, and students in developmental mathematics in particular, "need a multimodality instructional approach which means integrating the lecture with manipulatives, math study skills, and group work" (p. 22). Therefore, students who are academically at-risk and students in developmental programs may especially benefit from active learning teaching strategies. A classroom with active learning allows further student involvement with richer knowledge and better skills to explain problems and think analytically (Smart \& Csapo, 2007). Furthermore, use of active learning teaching strategies may result in an increase in student motivation and positive self-efficacy (Wadsworth et al., 2007).

Active Learning and Bloom's Revised Taxonomy

Bloom's revised taxonomy is a model that provides a theoretical construct for defining and better classifying active learning. The cognitive domain of the Bloom's revised taxonomy ranges from the lowest level, remembering, to the highest level, creating (Anderson \& Krathwohl, 2001). Tabrizi and Rideout (2017) define active learning as a system for engaging students in Bloom's revised taxonomy's higher-order thinking skills through the use of various activities (Tabrizi \& Rideout, 2017). It is hoped that as students are exposed to more active learning teaching strategies, they will begin to progress through Bloom's revised taxonomy and be able to apply those skills learned in other courses. Most educators develop questions for the higher levels of Bloom's revised taxonomy to improve and to gauge students' critical thinking skills (Fowler, 2006). Interactive teaching strategies like the ones used to engage students in active learning are believed to involve higher-level thinking skills, while traditional techniques are thought to elicit lower-level thinking skills. For example, students taking a large enrollment STEM course who were identified as under-represented or not under-represented were equally successful when active learning teaching strategies that targeted higher-order thinking skills were employed (Kressler \& Kressler, 2020).

\section{Institutional Type and the Carnegie Classifications}

Institutional type has been used in a variety of research studies. From studies on moral reasoning (Mayhew, 2012) to capstone courses (Grahe \& Hauhart, 2013) to teaching undergraduate economics (Becker \& Watts, 1996), institutional type has been considered as a possible influencing factor. Numerous systems exist to categorize institutional type, and one commonly used system is the Carnegie Classification of Higher Education Institutions (CCHEI). Developed by the Carnegie Commission in 1970, the Basic Classification was first available for everyone to use in 1973. Under the Basic Classification there are nine categories of different universities and colleges (CCHEI, n.d.). This study considers institutional type using a modified version of the CCHEI. Specifically, this study only considers students in their first year at bachelor's degree-, master's degree-, and doctoral degree-granting institutions. 
Based on the literature reviewed, this study attempts to close a gap in the relevant literature. We were not able to identify any studies that simultaneously addressed institutional type, active learning and traditional teaching methodologies, and classification of students who are academically at-risk and academically prepared.

\section{Methodology}

National Survey of Student Engagement (NSSE) According to Price and Baker (2012), the "NSSE is predicated on the assumption that certain student behaviors are indicators of students' engagement in the learning process" (p. 21). The NSSE Report Builder-Public 2017 and 2018 data was chosen for this study as it is from an international survey (NSSE, 2018) that included students at a variety of types of institutions, including both public and private institutions (Gonyea \& Kinzie, 2015) and numerous students across the country. Specifically, the NSSE Report Builder-Public 2017 and 2018 data set was utilized as it was the most current data set available. According to the National Survey of Student Engagement (2018), even though institutions must pay for participation, nearly 325,485 first-year students from the United States and Canada participated in the survey; around 1,020 institutions in total participated, with $8 \%$ of the institutions being Canadian. However, only results from 4-year or higher institutions in the United States were considered in this study due to possible differences in academic systems. Results from the survey give an approximation about the time undergraduates spent on schoolwork and what they got out of attending a higher education institution (NSSE, 2019).

Researchers used chi-square analyses to establish associations between the variables. The first chi-square test of proportions was performed to determine if the proportions differed by Carnegie Classification for the populations who were academically prepared and who were academically at-risk. Next, chi-square tests of independence were performed to determine if there were statistically significant associations between student academic levels (academically prepared or academically at-risk), course emphasis on learning activities (traditional or active), and Carnagie Classifications (doctoral-, master, or bachelor-degree awarding institutions).

\section{NSSE Variables and Characteristics}

A report was generated from the NSSE Report Builder-Public 2017 and 2018 (2018) considering first-year students and institution type (Carnegie Classification), academically prepared versus academically at-risk status (self-reported grades), and traditional-learning versus active learning classroom type (types of activities required in the courses and hours spent studying). Grouped descriptive statistics were employed as individual responses to survey questions, and student background characteristics were not available in the NSSE Report Builder-Public 2017 and 2018 data set.

\section{First Year}

For the purposes of this study, only students who were "First Year" in the United States were considered (NSSE, 2015, p. 3). Responses from students who were considered "First Year" were utilized because they represent all beginning students, those who were academically prepared and those who were academically at-risk (NSSE, 2015, p. 3). Using responses from those who have progressed further in their academic careers, such as a student classified as a "Senior," would self-select for students who were successful enough to progress (NSSE, 2015, p. 3).

\section{Carnegie System}

This study only considers first-year students at bachelor's degree-, master's degree-, and doctoral degree-granting institutions. Therefore, to better compare overall institutional types, the Carnegie Classification categories were coalesced in the NSSE Report Builder-Public 2017 and 2018 data to three institutional categories: bachelor's, master's, and doctoral degree-granting institutions.

\section{Academically Prepared and Academically At- Risk}

For the purposes of this study, students in the first year who in the NSSE Report Builder-Public 2017 and 2018 data had a self-reported average of " $A$ " or " $B$ " were considered academically prepared, and students in the first year who had a self-reported average of " $C$ " or lower were considered academically underprepared and were believed to be academically atrisk. The NSSE Report Builder-Public 2017 and 
2018 data does not record student background characteristics, such as high school grade point average, ACT scores, or SAT scores. Therefore, the NSSE Report Builder-Public 2017 and 2018 data was then grouped by the grade categories of "A and B" and " $C$ " or lower to consider academic preparedness (academically prepared or academically at-risk).

\section{Traditional Learning or Active Learning}

In order to capture data on instructional methodologies, responses for two questions from the NSSE survey were collected. The first question, "During the current school year, how much has your coursework emphasized the following?" (NSSE, 2015, p. 1), asked students to indicate the frequency that their coursework emphasized various types of learning strategies. For this study, the first type, "Memorizing course materials" (NSSE, 2015, p. 1) is considered a traditional learning technique. The three types of learning strategies considered as active learning techniques are: "Applying facts, theories, or methods to practical problems or new situations... Analyzing an idea, experience, or line of reasoning in depth by examining its parts...[and] Evaluating a point of view, decision, or information source" (NSSE, 2015, p. 1). "About how many hours do you spend in a typical 7-day week doing the following?"(NSSE, 2015, p. 1) was the second survey question with responses collected from the NSSE survey data. For the analylsis, researchers assumed that a greater number of hours spent in learning activities to be equated with meaningful, active engagement with the content.

\section{Limitations}

The first limitation is if the questions in the NSSE Report Builder-Public 2017 and 2018 data actually reflect the variables being studied: (a) Are self-reported grades a true measure of being academically at-risk? and (b) Do the self-reported learning activities correspond to the actual teaching methods utilized in the courses the students are taking? The second limitation is due to the nature of the survey instrument, as it "is a self-selected and voluntary survey" (Rabourn et al., 2018, p. 29) at both the individual response and institutional levels. Next, even though the NSSE Report Builder-Public displayed responses from students across the United States (NSSE, 2018), the responses will not be generalizable to a particular institution. Further, student background characteristics that were not assessed by the NSSE Report Builder-Public 2017 and 2018 data could compound or impact these results. Various causalities and correlational factors may influence self-reported grades other than academic preparedness, such as motivation, student age status, or hours of employment.

\section{Results}

Out of the 188,836 first year students surveyed in the National Survey of Student Engagement 2017 \& 2018, 173,579 were classified as academically prepared and 15,257 as academically at-risk (NSSE Report Builder-Public, 2018). See Table 1 for descriptive statistics regarding the numbers of students that were academically prepared and academically at-risk at the bachelor, master, and doctoral levels.

\section{Table 1}

Number and Percentage of Students by Academic Level and Carnegie Classification

\begin{tabular}{ccccccccc}
\hline $\begin{array}{c}\text { Academic } \\
\text { Level }\end{array}$ & \multicolumn{2}{c}{ Doctoral } & \multicolumn{2}{c}{ Master } & Bachelor & \multicolumn{2}{c}{ Total } \\
\hline & $\mathrm{n}$ & $\%$ & $\mathrm{n}$ & $\%$ & $\mathrm{n}$ & $\%$ & $\mathrm{n}$ & $\%$ \\
$\begin{array}{c}\text { Academically } \\
\text { prepared }\end{array}$ & 72,007 & 92.34 & 75,047 & 91.39 & 26,525 & 92.16 & 173,579 & 91.92 \\
$\begin{array}{c}\text { Academically } \\
\text { at-risk }\end{array}$ & 5,934 & 7.66 & 7,066 & 8.61 & 2,257 & 7.84 & 15,257 & 8.08 \\
\hline
\end{tabular}

\section{Chi-Square Analyses}

Researchers used numerical data available in the Appendix to perform all chi-square testing. First, a chi-squared test of proporations was used to determine if the distributions of students by academic level differed significantly across the Carnegie Classifications. There was a statistically significant association between student academic level and enrollment across bachelor's, master's, and doctoral degree-granting institutions, $\left.X^{2}(2, N=188,836)=55.543, p<0.001\right)$.

Researchers also conducted chi-square tests of independence for each type of learning activity reported by students as well as student study hours to observe any differences in survey responses from students who were academically prepared and those who were academically at-risk. Table 2 displays these chi-square results. The resulting $p$ values for students who were acadmecially prepared were statistically significant $(p<.001)$. For students who reported grades of $C$ or lower, the null hypothesis was rejected for all of the questions at the .001 or .05 significance level except for the "Evaluating a point of view, decision, or information source" (NSSE, 2015, p. 1), which had a $p$ value of 0.223 . This indicated that no association could be established between students who were academically at-risk and their survey responses for learning activities involving evaluation. 
Table 2

Chi-Square Results for Learning Activities Reported by Student Academic Levels

\begin{tabular}{|c|c|c|c|c|c|c|c|c|}
\hline \multirow{2}{*}{ Learning Activity Type } & \multicolumn{4}{|c|}{ Academically Prepared } & \multicolumn{4}{|c|}{ Academically At-Risk } \\
\hline & $x^{2}$ & $d f$ & $n$ & $p$ & $x^{2}$ & $d f$ & $n$ & $p$ \\
\hline \multicolumn{9}{|c|}{ Question 1: During the current school year, how much has your coursework emphasized the following? } \\
\hline Memorizing course material & 577.18 & 6 & 174,227 & $<.001$ & 49.01 & 6 & 15,313 & $<.001$ \\
\hline $\begin{array}{l}\text { Applying facts, theories, or methods to } \\
\text { practical problems or new situations }\end{array}$ & 254.64 & 6 & 174,127 & $<.001$ & 36.08 & 6 & 15,300 & $<.001$ \\
\hline $\begin{array}{l}\text { Analyzing an idea, experience, or line of } \\
\text { reasoning in depth by examining its parts }\end{array}$ & 168.88 & 6 & 173,987 & $<.001$ & 17.99 & 6 & 15,290 & .006 \\
\hline $\begin{array}{l}\text { Evaluating a point of view, decision, or } \\
\text { information source }\end{array}$ & 357.65 & 6 & 173,995 & $<.001$ & 8.21 & 6 & 15,276 & .223 \\
\hline \multicolumn{9}{|c|}{ Question 2: About how many hours do you spend in a typical 7-day week doing the following? } \\
\hline $\begin{array}{l}\text { Preparing for class (studying, reading, writing, } \\
\text { doing homework or lab work, analyzing data, } \\
\text { rehearsing, and other academic activities) }\end{array}$ & 1055.13 & 14 & 173,579 & $<.001$ & 65.87 & 14 & 15,257 & $<.001$ \\
\hline
\end{tabular}

Table 3

Learning Activity Responses Per Academic Level Per Carnegie Classification $(N=188,836)$

\begin{tabular}{|c|c|c|c|c|c|c|c|}
\hline \multirow{2}{*}{ Learning Activity Type } & \multicolumn{4}{|c|}{ Acadmically Prepared } & \multicolumn{3}{|c|}{ Academically At-Risk } \\
\hline & Responses & $\mathrm{DOC}^{\mathrm{a}}$ & MAS $^{b}$ & $\mathrm{BAC}^{\mathrm{c}}$ & Responses & $\mathrm{DOC}^{\mathrm{a}}$ & MAS $^{b}$ \\
\hline
\end{tabular}

Question 1: During the current school year, how much has your coursework emphasized the following?

\begin{tabular}{|c|c|c|c|c|c|c|c|c|}
\hline \multirow{4}{*}{ Memorizing course material } & Very little & 3.1 & 3.1 & 4.3 & Very little & 4.6 & 5.1 & 5.4 \\
\hline & Some & 24.8 & 24.9 & 29.7 & Some & 27.5 & 30.4 & 29.9 \\
\hline & Quite a bit & 46.2 & 47.0 & 45.6 & Quite a bit & 42.5 & 43.5 & 44.8 \\
\hline & Very much & 25.9 & 25.0 & 20.3 & Very much & 25.3 & 21.0 & 19.9 \\
\hline \multirow{4}{*}{$\begin{array}{l}\text { Applying facts, theories, or methods to } \\
\text { practical problems or new situations }\end{array}$} & Very little & 2.7 & 3.2 & 2.7 & Very little & 6.3 & 6.8 & 5.4 \\
\hline & Some & 22.9 & 24.8 & 22.5 & Some & 30.6 & 34.3 & 32.3 \\
\hline & Quite a bit & 47.7 & 48.5 & 49.4 & Quite a bit & 43.7 & 42.4 & 44.8 \\
\hline & Very much & 26.6 & 23.5 & 25.3 & Very much & 19.3 & 16.5 & 17.4 \\
\hline \multirow{4}{*}{$\begin{array}{l}\text { Analyzing an idea, experience, or line of } \\
\text { reasoning in depth by examining its parts }\end{array}$} & Very little & 3.2 & 3.2 & 2.5 & Very little & 6.1 & 6.6 & 5.0 \\
\hline & Some & 24.8 & 25.8 & 23.1 & Some & 32.2 & 33.9 & 32.9 \\
\hline & Quite a bit & 45.7 & 46.1 & 46.5 & Quite a bit & 42.3 & 42.2 & 43.0 \\
\hline & Very much & 26.1 & 24.7 & 27.7 & Very much & 19.3 & 17.2 & 18.7 \\
\hline \multirow{4}{*}{$\begin{array}{l}\text { Evaluating a point of view, decision, or } \\
\text { information source }\end{array}$} & Very little & 4.2 & 3.2 & 2.7 & Very little & 5.8 & 5.6 & 4.5 \\
\hline & Some & 26.4 & 25.1 & 23.0 & Some & 31.1 & 31.6 & 31.1 \\
\hline & Quite a bit & 45.1 & 47.3 & 47.4 & Quite a bit & 43.9 & 44.6 & 45.0 \\
\hline & Very much & 24.1 & 24.3 & 26.8 & Very much & 19.1 & 18.1 & 19.0 \\
\hline
\end{tabular}

Question 2: About how many hours do you spend in a typical 7-day week doing the following?

\begin{tabular}{|c|c|c|c|c|c|c|c|c|}
\hline \multirow{8}{*}{$\begin{array}{l}\text { Preparing for class (studying, reading, writing, } \\
\text { doing homework or lab work, analyzing } \\
\text { data, rehearsing, and other academic } \\
\text { activities) }\end{array}$} & $0 \mathrm{hrs}$ & 0.3 & 0.3 & 0.2 & $0 \mathrm{hrs}$ & 1.2 & 1.4 & 1.3 \\
\hline & $1-5 \mathrm{hrs}$ & 9.3 & 12.1 & 8.5 & $1-5 \mathrm{hrs}$ & 20.7 & 23.5 & 18.8 \\
\hline & $6-10 \mathrm{hrs}$ & 20.7 & 23.1 & 18.9 & $6-10 \mathrm{hrs}$ & 25.5 & 25.4 & 24.2 \\
\hline & $11-15 \mathrm{hrs}$ & 22.3 & 22.2 & 21.3 & $11-15 \mathrm{hrs}$ & 21.0 & 21.5 & 21.0 \\
\hline & $16-20 \mathrm{hrs}$ & 20.6 & 19.5 & 21.4 & $16-20 \mathrm{hrs}$ & 15.1 & 14.7 & 16.5 \\
\hline & $21-25 \mathrm{hrs}$ & 12.9 & 11.3 & 14.5 & $21-25 \mathrm{hrs}$ & 8.4 & 6.9 & 8.0 \\
\hline & $26-30 \mathrm{hrs}$ & 6.4 & 5.5 & 7.7 & $26-30 \mathrm{hrs}$ & 3.4 & 3.0 & 4.7 \\
\hline & $>30 \mathrm{hrs}$ & 6.5 & 5.2 & 7.0 & $>30 \mathrm{hrs}$ & 4.3 & 3.5 & 5.1 \\
\hline
\end{tabular}

Note. Values are expressed in percentages. For numerical values, see the Appendix.

${ }^{a}$ Doctoral degree-awarding institution. ${ }^{\mathrm{b}}$ Master degree-awarding institution. ${ }^{\mathrm{c}}$ Bachelor degree-awarding institution. 


\section{Analysis of Student Groups and Carnegie Classification}

Because the chi-square test results confirmed that there were statistically significant association between all but one interaction, further examination of the NSSE data was warranted. Table 3 shows a comparison by Carnegie Classification of traditional learning versus active learning for students who were academically prepared as compared to students who were academically at-risk. For ease of comparison, percentages are displayed for the number of first-year students responding for each of the composite Carnegie Classifications. The results from Table 3 are discussed from three main aspects: traditional learning, active learning, and hours spent studying.

Traditional Learning (Memorization)

Students who were academically at-risk at doctoral degree-granting institutions reported memorizing course content very much (NSSE, 2015 , p. 1) more frequently $(25 \%)$ than at either master's (21\%) or bachelor's degree-granting (20\%) institutions. Students who were academically prepared at doctoral degree-granting institutions reported memorizing course content very much (NSSE, 2015, p. 1) more frequently (26\%) than at bachelor's degree-granting (20\%) institutions but similarly to master's degree-granting $(25 \%)$ institutions (NSSE Report Builder-Public, 2018).

Students who were academically prepared and academically atrisk reported similar frequencies for the three active learning categories of applying, analyzing, and evaluating across all institution types. However, students who were academically at-risk reported lower very much use of active learning techniques across all instructional types. For example, at all institutional types, $24 \%$ to $27 \%$ of students who were academically prepared reported very much as their frequency of "Applying facts, theories, or methods to practical problems or new situations" (NSSE, 2015, p. 1), whereas only $17 \%$ to $19 \%$ of students who were academically at-risk reported very much as their frequency of "Applying facts, theories, or methods to practical problems or new situations" (NSSE, 2015, p. 1).

\section{Hours Spent Studying}

In terms of self-reported hours spent studying, at all institutional types, there is a considerable shift from the more limited hours spent studying by students who were academically at-

risk to the increased hours spent studying by the students who were academically prepared. For example, at all institutional types, $20 \%$ to $22 \%$ of students who were academically prepared reported spending 16-20 hours studying, whereas only $15 \%$ to $17 \%$ of students who were academically at-risk reported spending 16-20 hours studying (NSSE Report Builder-Public, 2018). When stepping away from the Carnegie Classifications and only looking at the hours spent studying for the academically prepared versus the academically at-risk groups, the percentage of students spending 0-10 hours was $32 \%$ for the academically prepared and $48 \%$ for the academically at-risk. However, when looking at more than 10 hours per week studying, the percentages for students who were academically prepared was $68 \%$, whereas the percentage for students who were academically at-risk was $52 \%$.

teaching

strategies do not imply that there

is only one way

to get students actively involved, but the use of a variety of teaching methods can enhance learning.

\section{Discussion}

As discussed previously, active learning teaching strategies engage the student, encourage greater involvement in the learning process, and encourage increased use of higher-level thinking skills. While our results indicated that students who were academically at-risk reported using traditional methods very much at similar rates to their peers who were academically prepared, students who were academically atrisk consistently reported very much using active learning strategies at much lower rates than their peers who were academically prepared. In addition, a lower percentage of students who were academically at-risk reported studying 16 or more hours a week than their peers who were academically prepared. Therefore, active learning strategies should be targeted for students who are academically at-risk to increase their engagement, study time, and performance. This is a general suggestion, as outside responsibilities, such as work and family, will vary for students and is not captured in this study; students who work more hours will likely have fewer hours to devote to study.

People learn in different ways, and learning is an active venture (Meyers \& Jones, 1993). Active learning teaching strategies do not imply that there is only one way to get students actively involved, but the use of a variety of teaching methods can enhance learning. Using multiple active learning strategies increases the student's ability to comprehend the course material and move on 
to their college-level courses (Fowler \& Boylan, 2010). Possible suggestions and tips to help students be successful in those first-year courses are below:

1. Include at least one active learning activity in your course to increase student participation.

2. Have students complete a collaborative project (Kuh \& AAC\&U, 2008).

3. Have students make connections from your course to other courses.

4. Use real world and/or problem-based teaching strategies.

5. Use gaming strategies to engage students in the classroom (Fulks \& Lord, 2016).

6. Implement High-impact Practices (Kuh et al., 2017).

7. Utilize a flipped classroom (Zamora-Polo et al., 2019).

Further, many students who are not college-ready require assistance in mathematics. Although the NSSE Report Builder-Public 2017 and 2018 does not allow for the segregation of data based on initial academic testing or specific content needs, one can assume that students earning grades of " $C$ " or lower in college may have some academic needs in mathematics. Mathematics is a course that many students need in college, and successful completion is a major goal for many students to graduate. Indeed, the enrollment in developmental mathematics courses at institutions of higher education is steadily increasing; therefore, educators are becoming accustomed to instructing students who are unprepared (Mireles et al., 2011). Students who take developmental mathematics courses are less likely to graduate, and most students are likely to repeat the course (Mireles et al., 2011). With the focus on getting students who are underprepared up to college level, mathematics will be a factor that will persist. This study suggests that students who are academically at-risk need to increase their study time and that instructors need to incorporate active learning teaching strategies to boost collegiate success rates.

\section{Implications}

Creating and providing quality instruction has become a major goal for many colleges and universities (Hall \& Ponton, 2005); and many institutions have devoted resources to create and to enhance programs targeted at students who are academically underprepared (Hall \& Ponton, 2005). One example of a potential enhancement, for institutions that provide admission to students who are academically atrisk, could be within departments that teach any freshman-level courses. The results of this study may help educators of all freshman-level courses more effectively prepare students who are academically at-risk by utilizing differentiated teaching strategies and helping faculty members to compare teaching methods. Additionally, the study may help educators of students in their first year to consider what teaching methods (i.e., active learning and/or traditional learning) may increase their students' performance, retention, and passing rates. In turn, students' academic performance may then be enhanced based on changes that faculty members may make to their instruction.

\section{Conclusions}

Results from the National Survey of Student Engagement 2017 and 2018 indicate that students who were academically at-risk report spending less time using the higher-order thinking skills associated with active learning (applying, analyzing, and evaluating) than their peers who were academically prepared. Not surprisingly, students who were academically at-risk reported fewer hours spent studying than their peers who were academically prepared (NSSE Report Builder-Public, 2018). These results could indicate that students who were academically at-risk had-poorer study habits, did not come to the institution with quality study strategies, or presented with more interferences to outside studying. Students who were academically at-risk may have reported fewer active learning strategies because they were not fully completing assignments, or they may have had instructors who were not utilizing active learning strategies.

More research is needed to consider whether instructors at all types of institutions are utilizing active learning or if students who are academically at-risk are not participating in the required class activities. Further, other studies controlling for student background characteristics, especially outside responsibilities such as employment and hours spent caring for family, are needed to delineate the effects of active learning on students who are academically at-risk.

\section{Future Research}

Generally, more research on active learning teaching strategies versus traditional instructional methods needs to be conducted to address additional teaching strategies, such as collaborative learning, high-impact practices, and gamification. Future research should include using data from the most current NSSE as it becomes available, especially as the COVID-19 pandemic could have created differences in institutional types, instructional strategies, and student characteris- 
tics. Future studies should also control for student background characteristics that were not assessed by the NSSE Report Builder-Public 2017 and 2018. Finally, other causalities and correlational factors that could influence self-reported grades, such as motivation, student age status, employment hours, and family responsibilities, should also be considered in additional research.

\section{Disclosure Statement}

No potential conflict of interest was reported by the authors.

\section{About the Authors}

Dr. Meredith Anne (MA) Higgs is an associate professor of University Studies at Middle Tennessee State University. She serves as the National Mathematics Network Co-chair for NOSS and is a well-respected speaker on learning assistance and general education mathematics. Dr. Higgs has been recognized at the local, state, and national level, including the Gladys R. Shaw Award for Outstanding Service to and Support of Student Success Programs.

Dr. Christina M. Cobb is an Assistant Professor in the University Studies Department teaching mathematics at Middle Tennessee State University (MTSU). She has been recognized at MTSU with an Outstanding Teaching award in fall 2019 and the 2021-2022 Inclusive Teaching Fellowship. She has presented numerous times nationally about innovative ways to teach mathematics and serves as the co-chair of the Mathematics Network for the National Organization for Student Success (NOSS).

Dr. Pamela Morris serves as an Associate Professor in the University Studies Department at Middle Tennessee State University. Her research interests are student success and engagement. She also serves as the Program Director for the Master's of Professional Studies and teaches professional studies courses at the graduate and undergraduate level.
References

Anderson, L. W., \& Krathwohl, D. R. (2001). A taxonomy for learning, teaching, and assessing: A revision of Bloom's taxonomy of educational objectives. Longman.

Becker, W. E., \& Watts, M. (1996). Chalk and talk: A national survey on teaching undergraduate economics. The American Economic Review, 86(2), 448-453.

Boylan, H. R. (2011). Improving success in developmental mathematics: An interview with Paul Nolting. Journal of Developmental Education, 34(3), 20-27. https://files.eric.ed.gov/fulltext/ EJ986275.pdf

Boylan, H. R., Bonham, B. S., \& Tafari, G. N. (2005). Evaluating the outcomes of developmental education. New Directions for Institutional Research, 125, 59-72.

Brothen, T., \& Wambach, C. (2012). Refocusing developmental education. Journal of Developmental Education, 36(2), 34-39. https://files.eric.ed.gov/ fulltext/EJ718687.pdf

Churach, D., \& Fisher, D. L. (2001). Science students surf the web: Effects on constructivist classroom environments. Journal of Computers in Mathematics \& Science Teaching, 20(2), 221-247.

Fowler, L. (2006). Active learning: An empirical study of the use of simulation games in the introductory financial accounting class. Academy of Educational Leadership Journal, 10(3), 93-103.

Fowler, P. R., \& Boylan, H. R. (2010). Increasing student success and retention: A multidimensional approach. Journal of Developmental Education, 34(2), 2-10. https://files.eric.ed.gov/fulltext/ EJ986268.pdf

Fulks, A., \& Lord, B. (2016). Leveling up in a gamified classroom. AMLE Magazine, 3(6), 41-43.

Gonyea, R. M., \& Kinzie, J. (2015). Independent colleges and student engagement: Descriptive analysis by institutional type. Council of Independent Colleges. https://files.eric.ed.gov/fulltext/ ED569195.pdf

Grahe, J. E., \& Hauhart, R. C. (2013). Describing typical capstone course experiences from a national random sample. Teaching of Psychology, 40(4), 281-287. https://doi. org/10.1177/0098628313501040

Grubb, N., \& Associates. (1999). Honored but invisible: An inside look at community college teaching. Routledge.

Hall, J. M., \& Ponton, M. K. (2005). Mathematics self-efficacy of college freshman. Journal of Developmental Education, 28(3), 26-32.

Kressler, B., \& Kressler, J. (2020). Diverse student perceptions of active learning in large enrollment stem course. Journal of the Scholarship of Teaching \& Learning, 20(1), 40-64. 
Kuh, G. D., \& Association of American Colleges and Universities. (2008). High-impact practices: What they are, who has access to them, and why they matter. Association of American Colleges and Universities. https://www.aacu. org/leap/hips

Kuh, G., O'Donnell, K., \& Schneider, C. G. (2017). HIPs at ten. Change: The Magazine of Higher Learning, 49(5), 8-16.

Lombardi, D., \& Shipley, T. F. (2021). The curious construct of active learning. Psychological Science in the Public Interest, 22(1), 8-43. https://doi. org/10.1177/1529100620973974

Lumina Foundation (n.d.). A stronger nation: Learning builds the talent that makes us rise. https:// www.luminafoundation.org/our-work/stronger-nation/

Mayhew, M. J. (2012). A multilevel examination of the influence of institutional type on the moral reasoning development of first-year students. The Journal of Higher Education, 83(3), 367388. https://doi.org/10.1353/jhe.2012.0020

McCarthy, J. P., \& Anderson, L. (2000). Active learning techniques versus traditional teaching styles: Two experiments from history and political science. Innovative Higher Education, 24(4), 279-294.

Meyers, C., \& Jones, T. B. (1993). Promoting active learning: Strategies for the college classroom. Jossey-Bass.

Mireles, S., Offer, J., Ward, D. D., \& Dochen, C. W. (2011). Incorporating study strategies in developmental mathematics/college algebra. Journal of Developmental Education, 34(3), 12-41.

National Survey of Student Engagement. (2015). National survey of student engagement: The college student report. https://tinyurl.com/ vw832xx9

National Survey of Student Engagement. (2019). About NSSE. https://nsse.indiana.edu/html/ about.cfm

National Survey of Student Engagement. (2018). Welcome to the NSSE report builder-public: Data file summary. http://bl-educ-cprtest. ads.iu.edu/SAS/rb nsse.html

NSSE Report Builder-Public. (2018). National Survey of Student Engagement 2017 \& 2018 [Data set]. http://bl-educ-cprtest.ads.iu.edu/SAS/ rb_nsse.html

Opdecam, E., Everaert, P., Van Keer, H., \& Buysschaert, F. (2014). Preferences for team learning and lecture-based learning among first-year undergraduate accounting students. $R e$ search in Higher Education, 55(4), 400-432. https://link.springer.com/article/10.1007\%2 Fs11162-013-9315-6
Price, K., \& Baker, S. N. (2012). Measuring students' engagement on college campuses: Is the NSSE an appropriate measure of adult students; engagement? The Journal of Continuing Higher Education, 60, 20-32. https://doi.org/10.1 080/07377363.2012.649127

Prince, M. (2004). Does active learning work? A review of the research. Journal of Engineering Education, 93(3), 223-231. https://onlinelibrary.wiley.com/doi/abs/10.1002/j.2168-9830.2004. tb00809.x

Rabourn, K. E., BrckaLorenz, A., \& Shoup, R. (2018). Reimaging student engagement: How nontraditional adult learners engage in traditional postsecondary environments. The Journal of Continuing Higher Education, 66, 22-33. https://doi.org/10.1080/07377363.2018.1415 635

Rachal, K., Daigle, S., \& Rachal, W. S. (2007). Learning problems reported by college students: Are they using learning strategies? Journal of Instructional Psychology, 34(4), 191-199.

Shi, Y., Peng, C., Yang, H. H., \& MacLeod, J. (2018). Examining interactive whiteboard-based instruction on the academic self-efficacy, academic press and achievement of college students. Open Learning, 33(2), 115-130. https://doi.or $\mathrm{g} / 10.1080 / 02680513.2018 .1454829$

Smart, K. L., \& Csapo, N. (2007). Learning by doing: Engaging students through learner-centered activities. Business Communication Quarterly, 70(4), 451-457. https://doi.org/10.1177/1080 5699070700040302

Tabrizi, S., \& Rideout, G. (2017). Active learning: Using bloom's taxonomy to support critical pedagogy. International Journal for Cross-Disciplinary Subjects in Education, 8(3), 3202-3209. https:// infonomics-society.org/wp-content/uploads/ ijcdse/published-papers/volume-8-2017/ Active-Learning-Using-Blooms-Taxonomy-to-Support-Critical-Pedagogy.pdf

The Carnegie Classification of Institutions of Higher Education. (n.d.). Basic classification description. http://carnegieclassifications.iu.edu/classification descriptions/basic.php

Wadsworth, L. M., Husman, J., Duggan, M., \& Pennington, M. N. (2007). Online mathematics achievement: Effects of learning strategies and self-efficacy. Journal of Developmental Education, 30(3), 6-14.

Zamora-Polo, F., Corrales-Serrano, M., Sánchez-Martín, J., \& Espejo-Antúnez, L. (2019). Nonscientific university students training in general science using an active-learning merged pedagogy: Gamification in a flipped classroom. Education Sciences, 9(4). https://files.eric.ed.gov/fulltext/EJ1238177.pdf 


\section{Appendix \\ NSSE 2017 \& 2018 First Year Students Frequency Data for Learning Activity by Academic Level and Carnegie Classification}

\begin{tabular}{|c|c|c|c|c|c|c|c|c|c|c|}
\hline \multirow{2}{*}{$\begin{array}{c}\text { Question and } \\
\text { Learning Activity }\end{array}$} & \multicolumn{5}{|c|}{ Academically Prepared (A and B) } & \multicolumn{5}{|c|}{ Academically At-Risk (C or Lower) } \\
\hline & Response & DOC $^{\mathrm{a}}$ & MAS ${ }^{b}$ & $\mathrm{BAC}^{\mathrm{c}}$ & Total & Response & DOC $^{\mathrm{a}}$ & MAS ${ }^{b}$ & $B A C^{c}$ & Total \\
\hline \multicolumn{11}{|c|}{ During the current school year, how much has your coursework emphasized the following? } \\
\hline \multirow{5}{*}{$\begin{array}{l}\text { Memorizing } \\
\text { course material }\end{array}$} & Very little & 2,244 & 2,313 & 1,143 & 5,700 & Very little & 276 & 364 & 122 & 762 \\
\hline & Some & 17,900 & 18,737 & 7,933 & 44,570 & Some & 1,641 & 2,154 & 678 & 4,473 \\
\hline & Quite a bit & 33,394 & 35,404 & 12,171 & 80,969 & Quite a bit & 2,533 & 3,083 & 1,016 & 6,632 \\
\hline & Very much & 18,751 & 18,815 & 5,422 & 42,988 & Very much & 1,508 & 1,486 & 452 & 3,466 \\
\hline & Total & 72,289 & 75,269 & 26,669 & 174,227 & Total & 5,958 & 7,087 & 2,268 & 15,313 \\
\hline \multirow{5}{*}{$\begin{array}{l}\text { Applying facts, } \\
\text { theories, or meth- } \\
\text { ods to practical } \\
\text { problems or new } \\
\text { situations }\end{array}$} & Very little & 1,987 & 2,387 & 725 & 5,099 & Very little & 373 & 480 & 122 & 975 \\
\hline & Some & 16,536 & 18,634 & 5,995 & 41,165 & Some & 1,824 & 2,428 & 732 & 4,984 \\
\hline & Quite a bit & 34,500 & 36,520 & 13,186 & 84,206 & Quite a bit & 2,604 & 3,006 & 1,015 & 6,625 \\
\hline & Very much & 19,228 & 17,689 & 6,740 & 43,657 & Very much & 1,152 & 1,170 & 394 & 2,716 \\
\hline & Total & 72,251 & 75,230 & 26,646 & 174,127 & Total & 5,953 & 7,084 & 2,263 & 15,300 \\
\hline \multirow{5}{*}{$\begin{array}{l}\text { Analyzing an idea, } \\
\text { experience, or line } \\
\text { of reasoning in } \\
\text { depth by examin- } \\
\text { ing its parts }\end{array}$} & Very little & 2,306 & 2,434 & 677 & 5,417 & Very little & 365 & 465 & 114 & 944 \\
\hline & Some & 17,943 & 19,443 & 6,164 & 43,550 & Some & 1,917 & 2,403 & 746 & 5,066 \\
\hline & Quite a bit & 33,055 & 34,687 & 12,393 & 80,135 & Quite a bit & 2,520 & 2,993 & 975 & 6,488 \\
\hline & Very much & 18,890 & 18,612 & 7,383 & 44,885 & Very much & 1,149 & 1,218 & 425 & 2,792 \\
\hline & Total & 72,194 & 75,176 & 26,617 & 173,987 & Total & 5,951 & 7,079 & 2,260 & 15,290 \\
\hline \multirow{5}{*}{$\begin{array}{l}\text { Evaluating a point } \\
\text { of view, decision, } \\
\text { or information } \\
\text { source }\end{array}$} & Very little & 3,013 & 2,444 & 715 & 6,172 & Very little & 343 & 395 & 101 & 839 \\
\hline & Some & 19,112 & 18,925 & 6,121 & 44,158 & Some & 1,853 & 2,236 & 705 & 4,794 \\
\hline & Quite a bit & 32,615 & 35,569 & 12,638 & 80,822 & Quite a bit & 2,614 & 3,161 & 1,020 & 6,795 \\
\hline & Very much & 17,434 & 18,253 & 7,156 & 42,843 & Very much & 1,136 & 1,280 & 432 & 2,848 \\
\hline & Total & 72,174 & 75,191 & 26,630 & 173,995 & Total & 5,946 & 7,072 & 2,258 & 15,276 \\
\hline \multicolumn{11}{|c|}{ About how many hours do you spend in a typical 7-day week doing the following? } \\
\hline \multirow{9}{*}{$\begin{array}{l}\text { Preparing for } \\
\text { class (studying, } \\
\text { reading, writing, } \\
\text { doing homework } \\
\text { or lab work, } \\
\text { analyzing data, } \\
\text { rehearsing, and } \\
\text { other academic } \\
\text { activities) }\end{array}$} & $0 \mathrm{hrs}$ & 209 & 216 & 61 & 486 & $0 \mathrm{hrs}$ & 72 & 96 & 29 & 197 \\
\hline & $1-5 \mathrm{hrs}$ & 7,181 & 9,089 & 2,259 & 18,529 & $1-5 \mathrm{hrs}$ & 1,231 & 1,662 & 426 & 3,319 \\
\hline & $6-10 \mathrm{hrs}$ & 14,967 & 17,392 & 5,024 & 37,383 & $6-10 \mathrm{hrs}$ & 1,517 & 1,801 & 548 & 3,866 \\
\hline & $11-15$ hrs & 16,094 & 17,098 & 5,678 & 38,870 & $11-15$ hrs & 1,253 & 1,523 & 477 & 3,253 \\
\hline & $16-20 \mathrm{hrs}$ & 14,880 & 14,665 & 5,712 & 35,257 & $16-20 \mathrm{hrs}$ & 898 & 1,039 & 374 & 2,311 \\
\hline & $21-25$ hrs & 9,351 & 8,539 & 3,857 & 21,747 & $21-25 \mathrm{hrs}$ & 500 & 486 & 181 & 1,167 \\
\hline & $26-30 \mathrm{hrs}$ & 4,647 & 4,123 & 2,056 & 10,826 & $26-30 \mathrm{hrs}$ & 205 & 209 & 107 & 521 \\
\hline & $>30 \mathrm{hrs}$ & 4,678 & 3,925 & 1,878 & 10,481 & $>30 \mathrm{hrs}$ & 258 & 250 & 115 & 623 \\
\hline & Total & 72,007 & 75,047 & 26,525 & 173,579 & Total & 5,934 & 7,066 & 2,257 & 15,257 \\
\hline
\end{tabular}

